\title{
PILEATED WOODPECKER NESTS AT GOOD SPIRIT LAKE
}

by Joyce Gunn, Box 549, Yorkton

Pileated Woodpeckers (Dryoscopus pileatus) have been seen in this area for the past two years, but not until the spring of 1968 was a definite nesting record established at Good Spirit Lake. In C. Stuart Houston's "Birds of the Yorkton district, Saskatchewan" (Can. Field-Nat., 63:215-41), the Pileated Woodpecker is described

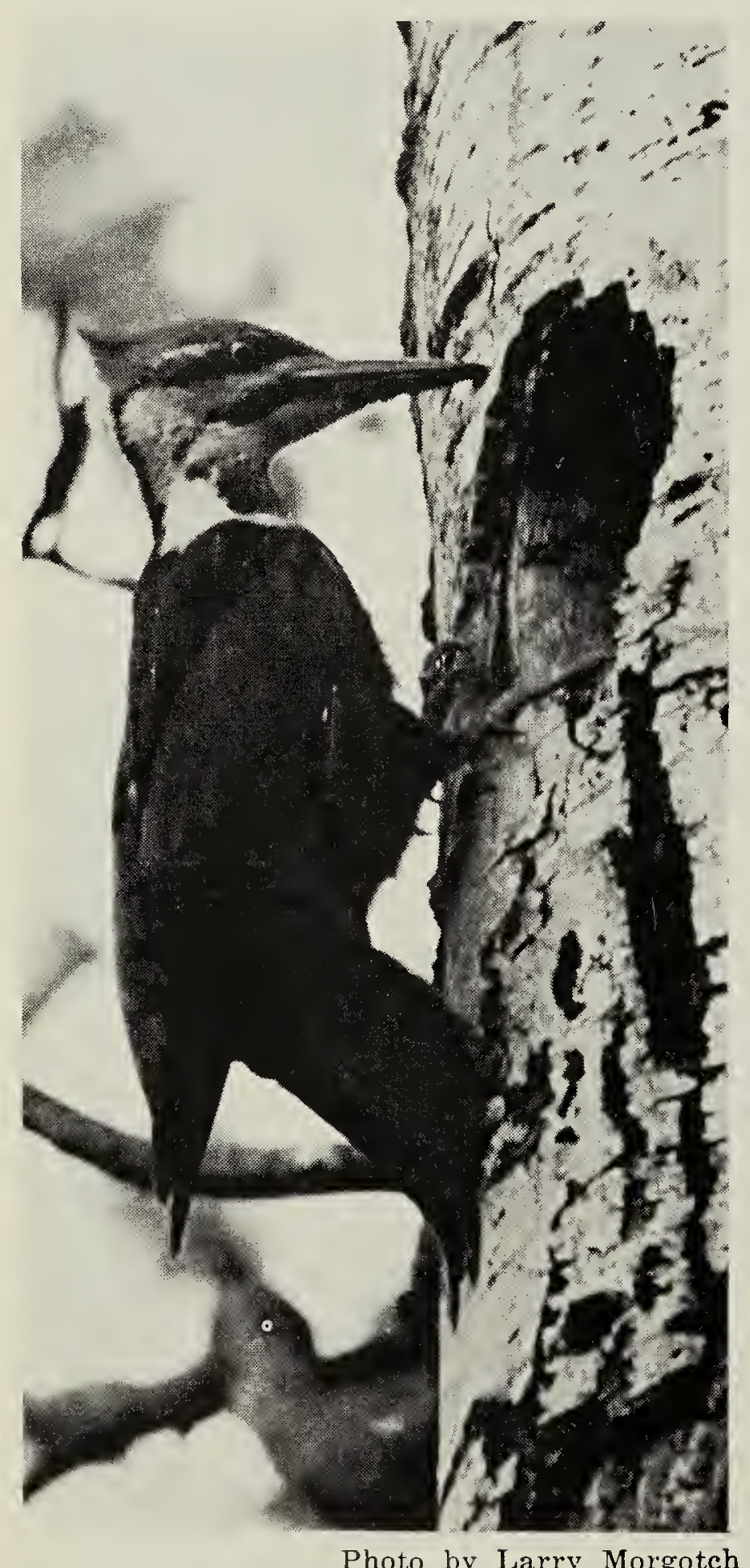

Pileated Woodpecker at Good Spirit Lake, June, 1968. as a bird of the northern woods, occurring at Crystal Lake, just north of the area covered by this list; and Houston reports that "J. Gunn noted only two individuals at Good Spirit Lake in sixty years; one of these was seen in autumn of about 1936, the other in the spring of about 1942."

My own sightings with a positive identification started here on April 1, 1967 and I heard, and occasionally saw, an individual diring that summer and fall. During the early spring of 1968 sightings became more frequent and in March, when the male was most vocal, I was able to locate the general "home" area. There had been a number of possible nesting holes made but the most likely one was found on April 7. It, and the other holes, were located in a large, live poplar on the northwest face of the tree about 18 feet above ground and only about 150 yards from Highway \#229 that leads to Good Spirit Provincial Park.

During the next few weeks the site was checked at various times by both Frank Switzer and myself without either of us seeing any sign of nesting. Finally, towards the end of April, I visited the site one morning and heard sounds of a bird working inside the tree and then saw the Pileated Woodpecker poke its head out to watch my dog prowling below. It watched the $\operatorname{dog}$ for a few minutes and then withdrew into the tree, out of sight.

From then on, the site was checked various times by Frank Switzer who got a photograph on May 26 of the nesting bird, and later more photographs of the young and parents. Larry Morgotch took the picture shown, in late June. It is not known how many young were raised at this nest but I later saw four Pileated Woodpeckers in a group. 